\title{
THE THIRD SECTOR AND THE GHANGING WELFARE STATE
}

\author{
Onur Kovaneı \\ Carleton University \\ Department of Sociology and Anthropology
}

\section{Üçüncü Sektör ve Değissen Refah Devleti Özet}

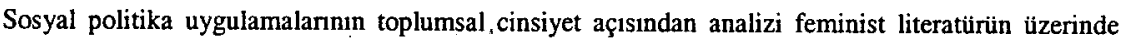
durduğu önemli konulardan biridir. Yakın zamanda yapılan çalı̧malar refah devletini toplumsal cinsiyet açısından sorgulamakta ve farklı ülkelerdeki benzerliklerin ve farklılıklann anlaşılmasında değerli analitik araçlar sunmaktadır. Bu çerçevede refah yardımlanının toplumsal cinsiyet ilişkilerini nasıl şekillendirdiği önem kazanmaktadır. Ancak refah rejimleri çalışmalanndaki temel yaklaşım bu boyutu dışlamaktadır. Rejim çalışmalannda metasızlaştırmanın sadece sosyal haklar çerçevesinde tanımlanması ve toplumšal cinsiyet boyutunun analize dahil edilmemesi feminist literatürün temel eleştirileri arasındadir.

Refah devleti sisteminin gelişmediği ülkelerde üçüncü sektör toplumsal cinsiyet boyutu taşıyan önemli bir refah kaynağı olarak gelişmektedir. Bu makalede Esping-Andersen' in yaklaş̧ımı toplumsal cinsiyet açısından ele alınırken üçüuncü sektörün ơnemine deģinilmektedir. istihdam.

Anahtar Kelimeler: Refah devleti, üçüncï sektör, toplumsal cinsiyet, mikro kredi, enformel

\section{Abstract}

The analysis of social policy practices from the point of gender is one of the important subjects in feminist literature. Recent studies have investigated the welfare state with respect to gender issues and provided valuable analytical tools in understanding the differences and the similarities in different countries. In this context, how the welfare subsidies shape the gender relations is of grave importance. However the mainstream welfare regime studies exclud this dimension. In the regime studies, the description of decommodification in the context of social rights and the exclusion of gender are among the main critiques of feminist literature.

In the countries where the welfare state is not developed enough, the third sector has been growing as a source of welfare, which has important outcomes from a gender perspective. In this article, while EspingAndersen's approach is analyzed from the point of gender, the importance of the third sector is touched upon.

Keywords: Welfare state, third sector, gender, micro credit, informal employment. 
female labor would have to ask for an increase in the 'family wage' in order to meet dependents' needs (MACKINTOSH, 1981: 8). This perspective more or less explains the function of unpaid work for capital. However, when it comes to the questions of why women are concentrated in specific working areas, why women's labor force participation is relatively low in the urban market and why women's career opportunities are interrupted from the outset, the functionalist interpretation seems insufficient. Therefore the analysis should go beyond the question of 'what are the benefits of women's labor for capital?'. This way it is possible to investigate the social and cultural factors as well as economic ones in women's role in social and economic development.

As many feminist researchers have pointed out, the gender division of labor existed even before the capitalist mode of production. So it can be argued that gender division of labor is not intrinsic only to capitalism, which led some streams of feminist researchers to switch their attention from relations of production to systematic relations 'of dominations,' called patriarchal structures. In this regard, the gender division of labor is considered as an intersection of capitalism and patriarchy, in which class, ethnicity and race make a difference. ${ }^{1}$

\section{Gendering Welfare State, Regimes: Some Limitations}

Providing different perspectives towards the welfare state, regime studies are central to the study of social policy. Firstly, regime studies provide important tools to understand the differences and similarities in different countries' social policies. According to O'Connor (1999: 12) regime studies are important since they form a model according to which different policy choices can be analyzed. Besides, then deepen the analysis beyond the functionalist interpretation of social policy, which sees social policy "as an automatic reflection of capitalist development (ORLOFF; 1993: 305). In regime studies, 'politics' is one of the determinant factors. The emphasis on political economy, class, and conflicts is the positive dimension of the regime model.

As many feminist scholars argue," regime studies lack gender analysis. In order to rectify this gap, feminist researchers have analyzed the basic concepts of regime studies and have brought up valuable critiques on the dominant understanding of social rights, de-commodification, women's interests, and social action. These studies point out the gender discrimination in the labor

1 I use the term 'patriarchy' to express every kind of male domination in social and economic life. 
market and reproduction of gender inequalities in social and economic life. Their most crucial contribution is to introduce the concept of 'unpaid work' into the analysis of the welfare state regimes. However, the mainstream regime studies still tend to ignore the gender relations between the sexes inside and outside the household (BRUSH, 2002: 165). ${ }^{2}$ Indeed, when we examine the works of Esping-Andersen, who is the most influential theoretician of this literature, we hardly see any reference to gender inequalities and reproduction of gender division of labor. According to Esping-Andersen, the quality of social rights, social stratification, and the relationship between state, market, and family, are the essential criteria to define welfare state regimes (ESPINGANDERSEN, 1990: 29 / 1999: 35). In his analysis, the nature of class mobilization, class-political coalition and historical inheritance of regime institutionalization are of importance. While analyzing the question of what the welfare state is, he rightly argues that the level of expenditure does not make sense on its own. Instead, he suggests looking at how state activities are connected to the market and family (ESPING-ANDERSEN, 1990: 21-22). However the argument does not move on to a gender analysis.

Esping-Andersen (1990) defines three distinct types of welfare regimes: liberal, social democratic, and corporatist models. His emphasis is mostly on the political economic dimension of the welfare state in particular on decommodification. De-commodification is thought as a result of social rights, which have the potential to free individuals from the pure liberal understanding of the labor market (BRUSH, 2002: 163).

In Esping-Andersen's studies, de-commodification is mostly studied within the context of welfare state programmes, such as unemployment, disability, sickness, and old age provisions. Andersen basically investigates to what extent the system of provision contributes to the de-commodification of labor, that is, protect the labor from the operation of the labor market. $\mathrm{He}$ argues that de-commodification exists only if any social service turns into a social right and if an individual maintains a secure life out of the free market economy (ESPING-ANDERSEN, 1990: 22). Considering the transformation of the Old Poor Laws (1601) into modern welfare practices in England it is clear that individuals with social and economic rights have more bargaining power in

2 In that sense, Brush names 'the mainstream welfare state regime literature' androcentric (BRUSH, 2002: 163). 
the market, as well as in other dimensions of social and economic life. ${ }^{3}$ However, in Esping-Andersen's approach, the fact that de-commodification is limited only to welfare state provisions seems problematic.

What is absent in Esping-Andersen's perspective is that, first of all, gender dimension is not included into the analysis. Secondly, he does not apply his triangular model to the question of the third sector. Since the main welfare suppliers are defined as the state and family, de-commodification in his conceptualization is mostly explained through non-market social provisions provided by the welfare state. For example, social policy in Esping-Andersen's perspective is considered as "the public management of social risks" (ESPINGANDERSEN, 1999: 36). At this point the importance of the third sector as a source of welfare is being neglected. However, there is a strong relationship between the welfare state and the third sector. When we take into account the rising importance of the third sector, the sources of welfare cannot be limited only to state, market, and family. 4

In the third sector, there are many non-familial, non-governmental, nonmarket initiatives that provide welfare services (BRUSH, 2002: 169). Some of these initiatives in developing countries target the poor, in particular women who have been excluded from the market and state provisions. These initiatives provide women with not only social services but also a social environment, where they can gain consciousness about their own interests. Through membership in these organizations women have access to welfare services and they also enter the public spheres as political agents, rather than passive welfare beneficiaries.

3 The English Poor Law is a turning point in the history of English social policy. The emergence of modern social security system is based on the historical evolution of Poor Law. Since the Old Poor Laws, known also as the Speenhamland System, guaranteed a minimum wage, it delayed the transformation of labor into a pure commodity. See, Polanyi, K. (1944) The Great Transformation, Toronto, Rinehart. Kovanc1, O (2003) Kapitalizm, Yoksulluk ve Yoksullukla Mücadelede Tarihsel Bir Deneyim: İngiliz Yoksul Yasaları, (in Turkish) Ankara, Mülkiyeliler Birliği Vakfı.

4 In the scheme that he develops by using Andersen's terminology, Salamon identifies three regimes in terms of two dimensions: The extent of social welfare expenses and the scale of the third sector. For Salamon, in the liberal model, low social welfare expenses mean large third sector whereas in the social democratic model, due to extensive social state services, the third sector is constrained. But Salamon states that even in this model NGOs can be politically active. Lastly, in the corporatist model the relationship between government and the third sector could be curvilinear (SALAMON, 1998: 229). 


\section{From the Formal Sector to the Informal Sector: Is the Welfare State Ready for this Transformation?}

The main characteristic of economic and social development from the Second World War until the 1970s was the standardization of products that could be achieved only in a capital-intensive mass production (SASSEN, 1997: 4). The full employment policy was another important aspect of mass production. During the Keynesian era the commitment to full employment enabled large-scale production. As a reflection of this economic policy, a wide range of social security precautions was developed. Besides being a leading force in the economy, the state was also responsible for providing the basic social services in the area of health, education, and social security. The idea underlying the state provisions was mainly about 'security' that encompasses upgrading of skills, securing workplace safety and social security (MAHNKOPF, 2003: 1-2).

Globalization is one of the impetuses for the transformation of the welfare state. It is a well-known fact that the decreasing role of the state in social and economic life has been the main characteristic of the last three decades. The changes in the capitalist development policies after the 1970s have not only affected the national social security systems but also caused important transformations in labor relations. Global trade and investment have changed the nature of employment as well as the triangular relationship between the state, employer and employee.

In developing countries, the impact of globalization is quite different. With the increasing competition in the market, many employers have tended to move their labor-intensive production units to low wage countries to escape the legal regulations. Under the pressure of rigid competitiveness, most of the formal entrepreneurs have begun to operate informally. Besides the economic crisis, decreasing power of unions, deregulation of labor relations has given rise to the informal economy. As a result, it has become more reasonable to talk about the production networks connected to each other rather than production units based on large-scale firms where thousands of workers are employed (CASTELLS, 2000: 29). The informal sector has expanded so much that, it is no longer considered as temporary stage for poor people's survival strategy but a new form of employment. Although the definition of the informal economy is highly debatable, the characteristics of informal economic activities can be summarized as follows: low wage, negative working conditions, insecureflexible jobs, the increase in child, migrant, and women's labor in specific sectors. 
While the new dynamics of industrial development have made important changes in social, economic and gender structure of society, the welfare state system is still based on the triangular relationship between the state, organized labor and capital owners and it lacks gender perspective. In the literature on the welfare state, the centrality of the national scale is still taken for granted (MAHON, 2003: 2). Additionally, access to rights is still related to membership to the nation state. However, for low-income people who are excluded from the rights of citizenship, formal membership means something different.

\section{Informal Security Nets: The Role of Non- Governmental Organizations}

The existing social security systems and welfare state provisions seem to be far away from capturing the new dynamics of reorganization of labor relations. The main actors in the social security system are still thought to be the employer who owns the factory where mass-production takes place and the employee who has a regular, full time job as in the past. This two dimensional structure is still the basis of labor laws and labor standards. However in developing countries, most workers do not fall into this employment category. With globalization, most workers are involved in more than one employment category. In more concrete terms, with the changing nature of employment relations, it has become difficult to identify the lines between different forms of employment. For instance, according to a survey of 5000 SEWA members in India, only $20 \%$ of members have one type of work, $40 \%$ do one additional job, $25 \%$ do three types of work, and $14 \%$ do more than four jobs (JHABVALA, 2004: 3). As these statistics show, the regular full time work and the idea of the mass production, on which welfare state is constructed, may no longer be sufficient to meet the new demands in the changing labor market.

Global trade and investment have different outcomes in developed and developing countries. In developing countries, particularly in the manufacturing sector, informal economic activities such as unlicensed factories, home-based work, and outsourcing have been increasing. The increase of women's employment in developing countries mostly takes the form of home-based work in the manufacturing sector. For instance, In India, women workers constitute $96.5 \%$ of the total employment in the informal sector (SEWA, 2002a: 3). As a result of the increase in the informal activities, many home-based workers face job insecurity and unhealthy working conditions. Under these conditions, lowincome women in developing countries have little or no access to social security. Therefore, to increase their bargaining power and access to productive sources are crucial. 
Besides their unpaid workloads in the household, increasing participation of women in the labor market makes them more vulnerable to social and economic changes. These dimensions of the changing labor relations call for new policies towards women's subordinate position in social and economic life. The pressure to affect or change the policies comes from the feminist social movement and non-governmental women's organizations. The first claim is that modern welfare state structure, based on the idea of bread winner model, is no longer appropriate for individuals' new demands, located in different economic and social positions. It is argued that the centralized, standardized gender-biased welfare state perspective is insufficient for the changing labor relations. In this regard, the welfare state has been accused of being dominated by patriarchal social relations (BROWN et.al, 2002: 161).

In the context of declining social services provided by the state and in response to the social and economic hardships in developing countries, there has been an increasing interest in the role of the third sector. The third sector can be conceptualized as a distinct sphere operating beside state institutions, market and family. As part of the third sector, NGOs in developing countries are involved in a variety of activities including charity services, technical support, implementation of government and local development programmes, and provision of social and welfare services (CLARK, 1991). Although there is not a clear line between the terms 'sector', 'voluntary', and 'non-profit', Salamon (1998: 216) defines the main characteristics of NGOs as follows;

- NGOs are organizations although they differentiate themselves from other bureaucratic organizations

- They are outside the governments' direct regulations

- They are non-profit. They can earn profits but distribute them to their members

- They are self-governing

- They are voluntary

In sum, NGOs can be conceptualized as the basic welfare service suppliers beyond the state, market, and family.

Without enough social protection, women in the third world are more vulnerable to social and economic development. The advocators of the third sector argue that NGOs have the capacity to create mutuality, solidarity, and equality. NGOs, with their flexible organizational structures, in some respects, seem to be more heterogeneous and responsive to the needs of the individuals at the local level than welfare programmes. 


\section{Micro-Credit Institutions: A Local Response to Commodification}

Women's unpaid work is generally devalued since the logic of capitalist development gives more importance to the exchange value and economic efficiency. In fact there are many economic activities that women take part in. These activities range from earning additional income and reproduction of labor to community work in rural and urban areas. However, since this kind of labor does not have exchange value in the economic sense, the reproductive activities of women are not considered as important as their paid work (MOSER, 1989: 158-159).

In the feminist literature, the government policies regarding welfare and development are classified in different categories. As a final stage, the empowerment approach states that capitalist development affects women's position negatively. ${ }^{5}$ According to this approach, women should be active participants in the labor force and earn their own well-being as a practical gender need. It is stated that by entering the market, women will be empowered in every sense. The empowerment here is not only related to the ability to use power but also to the access to power (ROWLANDS, 1998: 17). That is because, the empowerment approach points to the necessity of the struggle at different levels. In order to fulfill this aim, re-distribution of power inside and outside the household is considered to be the most effective way to empower women.

The empowerment approach is based on a critique of the equity and welfare approaches. One critique against the equity approach is that it seeks an equal society where women do not have any say to determine the process. The second critique is related to the ways chosen in dealing with gender inequalities. While the equity approach is more positive towards legal regulation from top to down, the empowerment approach offers women's participation in economic life as a tool. In that sense, besides the removal of legal constraints, women's mobility, consciousness and education have become important tools in empowering women.

Another critique of the empowerment approach is towards the welfare approach. As mentioned before, the welfare approach considers women's activities important only if they are productive. This generally excludes

5 Chronologically the other categories are described as 'welfare', 'equity', 'poverty', 'reduction' and efficiency (MOSER, 1993). 
women's reproductive role. However, the empowerment approach approves of women's multi-dimensional roles (MOSER, 1993: 76).

The empowerment approach has been accepted as a strategy by many women's organizations in developing countries. With respect to the services they provide, these initiatives have become an important source of welfare at the local level. In particular, NGO based micro-credit programmes, in which empowerment is considered as the main objective, have been on the agenda of many development practitioners for the last three decades.

\section{A Different Model From Formal Institutions: Micro-credit Institutions}

Micro-credit institutions generally aim to reach the poorest of the poor in rural areas in developing countries. The objective is to reach those who have few or no property. It is very difficult for this segment of the population to have access to credit facilities, because;

- Private banks require collateral for the loans they provide

- The majority of the women wishing to take loan are illiterate, which is an important disadvantage during the application for loan

- Formal banks are not sensitive enough to gender inequalities (OSMANI, 1998: 68).

\section{The Leading Micro-Credit Initiatives: Grameen Bank and SEWA}

The term 'Grameen' means 'rural' in Bangladeshi. The first micro-credit initiative started in the 1970 s with the initiative of well-known economist Muhammad Yunus. In the beginning, the initiative was limited to certain districts in Bangladesh, but later it spread to around 45.000 villages in the country. As of January 2004, the Bank's cumulative amount of credit disbursed is 4.18 Billion USD. Currently 3.12 million people, 95 percent of whom are women, are receiving micro-credit. ${ }^{6}$

The bank is basically different from other institutions in five points:

6 For more details about the latest statistics on Grameen Bank current's situation see; http://www.grameen-info.org/index.html (2004) 
1. The main target is the poorest of the poor.

2. The Bank provides small loans without collateral. This characteristic makes it easier for women to enter the market and earn a living without depending on their husbands. When women are not able to repay the loan, the bank neither asks help from the police nor takes the issue to court. Instead, the main reasons that lead women to this situation are analyzed and women are given additional loans. If the groups cannot work together anymore or cannot pay installments, the debt is noted in the expenses category (MALLICK, 2002: 153).

3. The bank itself contacts women who are willing to take credit. Considering the lack of women's mobility due to social and cultural constraints in Bangladesh, this makes it easy to reach women at their dwellings.

4. The bank places women on a high priority for credit. In other words, the bank is sensitive to gender inequality. As a result, in Grameen Bank, 95 percent of its members are women. ${ }^{7}$

5. Lastly, compared to other formal banks that require long bureaucratic processes, the application procedure is quite simple (BERGER, 1989: 10221024).

The Grameen Bank with its specialized method is one of the well-known models in the micro-credit field. The economic impact of the Grameen Bank has been examined in different studies. It is mostly argued that the loans result in an increase in employment compared to other women who do not take any credit. Besides its economic impacts, it is believed that micro-credit results in an increase in food consumption and investments in education and health of the household members. In addition, it improves women's mobility, economic security, and women's participation in decision-making processes (HASHEMI / MORSHED, 1997). However, when we take a closer look at the services Grameen Bank provides, the perception of service is limited to micro-credit. So, it can be argued that in this perspective the expectations from women's empowerment may be limited since women may need more than just microcredit. Skill upgrading, health and child-care services and access to market are among women's most urgent needs.

7 Female membership is also high in micro-credit institutions in other countries. For instance, in Bolivia the percentage of women involved in micro-credit programmes is $60 \%$, in the Philippines and Kenya it is $70 \%$. Considering the low level of women participation in loans in the formal banking system these rates are very high. 
The other important initiative in the area of micro-credit in the third sector is the Self-Employed Women's Association (SEWA). SEWA originated from the Textile Labor Association. Since its inception in 1972, it has represented around 6 million women working in the informal sector in India. ${ }^{8}$ SEWA with its unique model is different from other conventional trade unions. While most unions are organized only in one industry and exclude issues related to women, SEWA is one of the unique organizations based on female membership. Apart from providing credit, SEWA is very active in different areas such as maternity protection, skills training and health and elderly care services. The underlying assumption for these services is that the subordinated status of women can only be eliminated by an integrated approach, in other words, a 'holistic' approach. This way, SEWA aims to overcome the 'minimalist'credit only approach.

In the beginning, SEWA was working in cooperation with national banks to provide credit. The banks used to lend credit through SEWA. However, over time as repayment problems began to surface, SEWA realized that women's lives needed to be viable before expecting any success from the loans. Unexpected illness in the family, unsteady employment of the husband, pregnancies which influence women's work, no access to cheap raw materials or the market, expensive social traditions such as marriages, deaths and religious ceremonies are the main reasons behind the difficulties in repayment (ROSE, 1992: 53). With respect to micro-credit, SEWA began lending credit from its own funds in 1976.

What makes SEWA initiative so important is the other services it provides. For providing a social security service, SEWA has been organizing cooperatives. Artisan cooperatives, dairy cooperatives, land and service cooperatives are some of them. The service cooperatives include childcare and health care services provided by women (SEWA, 2002b: 209). Training is another component of this cooperative movement. For example, the 'Exposure Programme', organizes trips so that women have chance to see all steps of any production from the village to the market. For instance, for women who have never been out of the village and for those who do not know how milk is transported, processed, and distributed, the programme is multifunctional. SEWA organizes skill training through a number of ways working with

8 'Self-employment' is a broad term including all workers who are not in a formal employment relationship. The categories of SEWA are home-based workers, vendorstraders, agricultural workers, cleaners, street vendors, waste-paper pickers and small producers (SEWA, 2002a: 5). 
cooperative unions, government extensions, the Labour Department, voluntary agencies, vocational schools, village council training institutes, universities and industrial boards (SEWA, 2002b: 216). The training programmes include cooperative management, legal issues, functional literacy, marketing and communication. By means of credit and training programmes women have more bargaining power against middlemen (CARR et.al, 2000: 137).

SEWA has been trying to provide such services by training low-income women. With this objective the training programme aims to teach women how to run child care services and become more accountable for community health in their neighborhoods. Considering the difficulties for women workers in combining childcare and working at the same time, these cooperatives are quite critical for women's empowerment and participation in economic activities (SEWA, 2002b: 238). That is why the main focus for SEWA has been child care services to facilitate opportunities for full employment. ${ }^{9}$ SEWA is also active in health care services. The initiative helps its members obtain health care by means of cooperatives run by women themselves. The underlying idea is 'health education' and 'curative care'. ${ }^{10}$ In SEWA's experience, there is also an effort to establish relations with government institutions. With this holistic approach, the initiative aims to improve social and economic empowerment of women.

The empowerment dimension of women's organizations forms a new kind of social security net, which differs from other state provisions, organized at the national level. By organizing locally and focusing on specific segments of the population which are excluded from formal employment relations and formal social security systems, bottom-up movements are becoming more important. These initiatives create different options for women to obtain social welfare services and to avoid degrading forms of patriarchal welfare services. This way, they also have important influences on governments in terms of transforming the welfare state policies. However, as Padamsee and Adams (2002: 194) state, the final outcome of the de-commodifying aspect of welfare services at the local level depends on the scale of services provided and their capacity to ensure minimum life conditions for their members. Considering the

9 As of 2002, the number of childcare centers is 128 . In four different districts, the number of children receiving childcare services is around 6.268 (SEWA, 2002b: 33).

10 In year 2002, the number of people including children who received health care service is 45.551 . 
sustainability of such initiatives such as micro-credit programmes, this objective seems uncertain at least for the short term.

\section{Conclusion}

The third sector has generally been overlooked in the debates on the welfare state. For instance in the mainstream literature on welfare state regimes, welfare services are limited to the state, market and family. However within the process of globalization, besides the welfare provisions, the third sector has become an important actor in terms of goods and services it provides.

The new dynamics of global inequalities create new demands and new areas of struggle. The bottom-up movement is the center of this development. Both in developing and developed countries, these initiatives can create new demands for rights outside the normative definitions of the state and national laws. This goes hand in hand with the extension of the scope and perception of citizenship.

Within the process of globalization, new demands necessitate new policies. However, traditional welfare state approaches treat the third sector as a residual category. For the dominant perspective, what the NGOs do is to correct the disorders of formal state institutions, market and family. Limiting the multidimensional roles of the NGOs would be too functionalist since the NGOs, as social agents, also act, affect and change the transformation of the welfare state. On the other hand, to what extent the NGOs can meet individuals' welfare needs is very debatable. Indeed, when we look at the scope of the welfare provisions at the local level one can argue that the final impact of local initiatives is at the micro level. In addition, there are some social and economic issues that can be dealt with only at the macro level such as poverty, creating employment. Therefore, it may be misleading to assume that third sector organizations can be an alternative to welfare state. On the contrary, these activities should be seen in relation with welfare state provisions in terms of creating social safety net in a broader context. Especially, within the debates of globalization, there has been a tendency that approaches the third sector organizations as tools of neo-liberal reconstruction. In this perspective, the third sector organizations are seen as a substitute to welfare state that neo-liberal ideology wants to give up while dealing with social and economic problems. Therefore it is important to analyze the role of the third sector organizations by taking into account the reconstruction of the global economic structure.

With the growing importance of NGOs, the current developments call for changes on two levels. First of all, welfare programmes need to be reconceptualized and analyzed from a gender perspective. Secondly, such an 
analysis should go beyond the notion of welfare state services and also take the decommodifying aspects of the third sector into consideration. In conclusion, the integration of the third sector into the analysis will enable welfare state studies to further the conventional analyses that explain the present transformation with reference only to external factors such as globalization. Such an approach will certainly be useful to better understand the transformation of the welfare state.

\section{References}

BERGER, M. (1989), "Giving Women Credit: The Strengths and Limitations of Credit as a Tool for Alleviating Poverty," World Development, Vol. 17/7: 1017-1032.

BROWN, K.M. / KENNY, S. / TURNER, B.S. (2002), "A basis for association? The role of third sector welfare organizations," Community, Work \& Family, Vol. 5/2:159-180.

BRUSH, Lisa D. (2002), "Changing the Subject: Gender and Welfare Regime Studies," Social Politics, Vol. 9/2: 161-186.

CARR, M. / CHEN, M. A. / TATE, J. (2000), "Globalization and Home-Based Workers," Feminist Economics, Vol. 6/3: 123-142.

CASTELLS, M. (2000), The Rise of The Network Society, second edition, Vol.1, Blackwell Publishers.

CLARK, J. (1991), Democratizing Development (London: Earthscan Publications Ltd.)

ESPING-ANDERSEN, G. (1990), The Three Worlds of Welfare Capitalism (Cambridge: Polity Press).

ESPING-ANDERSEN, G. (1999), Social Foundation of Postindustrial Economies (Oxford: Oxford University Press).

HASHEMI, S.M. / MORSHED, L. (1997), "Grameen Bank: A Case Study," WOOD, Geoffrey D. I SHARIF, Iffath A. (eds.), Who Needs Credit (London: Zed Books).

JHABVALA, R. (2004), Excluding the Majority: Workers, Producers and Categories of Employment, SEWA.

KOVANCI, O (2003), Kapitalizm, Yoksulluk ve Yoksullukla Mücadelede Tarihsel Bir Deneyim: Ingiliz Yoksul Yasalan (in Turkish) (Ankara: Mülkiyeliler BirliğiVakfı).

MACKINTOSH, M. (1981), "Gender and Economics: The Sexual Division of Labour and The Subordination of Women," YOUNG, K. / WOLKOWITZ, C. / MCCULLSGH, R. (eds.), of Marriage and the Market (London: Routledge).

MAHNKOPF, B. (2003), "The Future of Work," http://www.goethe.de/br/poa/wsf/mahnde.htm

MAHON, R. (2003), "Yet Another R? Restructuring and Rescaling the Welfare State," Revised version of a paper presented at the workshop of the ISA Research Committee, University of Toronto.

MALLIC, R. (2002), "Implementing and Evaluating Microcredit in Bangladesh," Development in Practice, Vol. $12 / 2$.

MOSER, C. (1989), "Gender Planning in the Third World: Meeting Practical and Strategic Gender Needs," World Development ${ }_{2}$ Vol. 17/11:1799-1825.

MOSER, C. (1993) Gender Planning and Development, Theory, Practice and Training, (London: Routledge).

O'CONNOR, J. I ORLOFF, A. / SHAVER, S. (1999), States, Markets, Families: Gender, Liberalism and Social Policy in Australia, Canada, Great Britain and The United States (Cambridge: Cambridge University Press). 
ORLOFF, A. S. (1993) "Gender and Social Rights of Citizenship: The Comparative Analysis of Gender Relations and Welfare States," American Sociological Review, Vol. 58/3.

OSMANI, L. (1998), "Grameen Bank Experiment: Empowerment of Women Through Credit," AFSHAR, $\mathrm{H}$ (eds.) Women and Empowerment: Illustration from the Third World (London: Macmillan Press).

ROSE, K. (1992), Where Women Are Leaders, The SEWA Movement in India (London: Zed Books).

PADAMSEE, T. / Adams, J. (2002), "Signs and Regimes: Rereading Feminist Work on Welfare States," Social Politics Vol. 8/1:187-202.

POLANYI, K. (1944), The Great Transformation (Toronto: Rinehart).

ROWLANDS, J. (1998), "A Word of the Times, but what does it mean? Empowerment in the Discourse and Practice of Development," AFSHAR, H. (eds.) Women and Empowerment: Illustration from the Third World (London: Macmillan Press).

SALAMON , L.M. / ANHEIER, H.K. (1998), "Social origins of Civil Society: Explaining the Nonprofit sector cross-nationally," International Journal of Voluntary and Nonprofit Organizations, Vol. 9/3: 213-248.

SASSEN, S. (1997), "Informalization in advanced market economies, Issues in Development," Discussion Papers, ILO.

SEWA (2002a), "Globalization and its Impact on Women Workers In The Informal Economy," Workshop, Unifem and Global Network.

SEWA (2002b), Annual Report, Shri Mahila Sewa Trust, http://www.sewa.org/annualreport/areng-1.pdf 